\title{
Analysis of the In Vitro Secretory Activity of Human Pituitary Adenomas: Modification of Corticotropin Release from Adenoma Tissue Explant Cultures by Addition of a Human Plasma Ultrafiltrate Bioactive Fraction
}

\author{
Neven Žarković1 ${ }^{1,2}$, Marianne Hayn ${ }^{2}$, Vesna Plavšić ${ }^{3}$, Kamelija Žarkovićc ${ }^{4}$,Joško Paladino ${ }^{5}$, Nevenka Hiršl ${ }^{1}$, \\ Jasminka Golubic ${ }^{1}$, Simon Mikulandra ${ }^{6}$, Dunja Rogic ${ }^{3}$, Branka Salzer ${ }^{7}$, Biserka Pokrić ${ }^{1}$, Rudolf Jörg Schaur ${ }^{2}$, \\ Franz Tatzber ${ }^{2}$, Heinz Faulhammer ${ }^{8}$, Bojan Benko ${ }^{9}$. Walter Dietrich ${ }^{10}$, Mislav Jurin ${ }^{1}$ and Mirko Koršić ${ }^{6}$ \\ 1 "Rudjer Boskovic" Institute, Zagreb, Croatia \\ 2 Institute of Biochemistry, Graz, Austria \\ 3 Clinical Hospital Centre "Rebro", Laboratory of Endocrinology, Zagreb, Croatia \\ 4 Clinical Hospital Centre "Rebro", Institute of Neuropathology, Zagreb, Croatia \\ 5 Clinical Hospital Centre "Rebro", Clinic for Neurosurgery, Zagreb, Croatia \\ "Clinical Hospital Centre "Rebro", Clinic for Internal Medicine, Zagreb, Croatia \\ 7 Clinical Institute of Laboratory Diagnosis, University Clinic "Rebro", Zagreb, Croatia \\ 8 Institute of Biochemistry, Bayreuth, Germany \\ 9 Institute of Immunology, Zagreb, Croatia \\ 10 University of Oldenburg, Oldenburg, Germany
}

Summary: The lack of control of tumour behaviour is manifested in different ways, depending primarily on the type of tumour. This results in numerous problems of tumour diagnosis and therapy. In the case of "benign" tumours, like pituitary adenomas, in vitro studies are often used for evaluation of the tumour. The use of tissue explant cultures of human pituitary adenomas and the comparison of the feature of cultured tumours with their behaviour in vivo showed that corticotropin is released not only from the tumours associated with Cushing's disease, but also from clinically non-functioning tumours. Hence, it was supposed that the release of corticotropin in vivo from non-secreting tumours is probably under the influence of certain neuroendocrine and/or systemic humoral factors. To test this possibility, samples of 22 tumours were cultured in plain culture medium or in the presence of the "human plasma ultrafiltrate bioactive fraction" (tentatively termed as TBP) prepared by anion-exchange chromatography. In the presence of TBP the release of corticotropin was strongly inhibited in adenomas showing relatively high spontaneous secreting activity in vitro ( $>200 \mathrm{ng} / 1$ in 24 hours), while immunohistochemistry of these tumours indicated accumulation of corticotropin inside the cells. In contrast, TBP stimulated corticotropin release from tumours that showed relatively low basic corticotropin release ( $<200 \mathrm{ng} / 1$ in 24 hours), with no obvious change in cellular corticotropin immunoreactivity. Such a dual activity of TBP was not observed for 8 samples of adenomas cultured in the presence of surrounding pituitary tissue, probably because TBP did not affect corticotropin secretion by the normal pituitary cells (as indicated by immunohistochemistry). From these results, it appears that TBP could be one of the humoral factors involved in the regulation of corticotropin release from pituitary adenoma tissue. Its possible involvement in the regulation of corticotropin release from normal pituitary tissue, however, is uncertain.

\section{Introduction}

By measuring blood hormone concentration, pituitary adenomas are classified in vivo as "non-secreting" (clinically non-functioning tumours) or as hormone-secreting adenomas which cáuse recognised clinical disturbances (galactorrhoea and oligomenorrhoea, acromegaly, Cushing's disease, etc.) $(1-3)$. The use of in vitro cultures of pituitary adenomas and comparison of the features of the cultured tumours with their behaviour in vivo revealed further variability of morphological features and hormone secreting activity (4-8). This in vitro analysis of the characteristics of pituitary tumours also provides a basis for research on the activity of factors that might be involved in the regulation of tumour behaviour $(9,10)$.

However, it is not known whether adenoma cells are subject to control by the neuroendocrine system. The nature of factors that might be involved in the regulation of hormone secreting activity of pituitary adenomas is 
also unknown. Thus, tumours associated with clinical evidence of hormone excess show high hormone secreting activity if cultured in vitro, but clinically "non-functioning" tumours also display a low level of hormone secreting activity in vitro $(4,6)$. Most of clinically "nonfunctioning" tumours, null cell adenomas and oncocytomas secret follitropin and lutropin in vitro, but occasional tumours (like normal pituitary gland) release somatotropin, prolactin and corticotropin, as well (6). Similarly, we have noticed that in pituitary adenomas cultured in vitro for 24 hours as tissue explant cultures (intact samples of the tumourous tissue), the release of corticotropin does not correspond to the hormonal activity of the tumours in vivo (11).

Hence, it seems that the secretory activity of pituitary tumours may be influenced by systemic regulatory mechanisms, probably mediated by hypothalamic as well as by certain humoral factors. To test this possibility and to further evaluate the hormone secreting activity of pituitary tumours, their sensitivity to the "bioactive fraction of the human plasma ultrafiltrate", tentatively termed as $\mathrm{TBP}^{1}$ ), (12) was analysed in vitro.

\section{Materials and Methods}

\section{Patients}

Pituitary adenomas of 22 patients were analysed (tab. 1). Eleven patients ( 5 male and 6 female) 25-76 (52 \pm 18 ) years old had clinically non-functioning tumours. All of them had visual disturbances and headaches, and preoperative CT imaging scans demonstrated a macroadenoma. Basal serum levels of hormones were in the reference range, except prolactin which was elevated in 5 patients $(60.7 \pm 20.9 \mu \mathrm{g} / \mathrm{l})$ due to the stalk compression.

Five female patients, $29-40$ (30 \pm 5$)$ years old, presented with the syndrome of galactorrhoea and amenorrhoea associated with elevated serum prolactin levels $(185.2 \pm 59.1 \mu \mathrm{g} / \mathrm{l})$. Three men, $28-57(42 \pm 14)$ years of age, also had elevated serum prolactin levels $(274.1 \pm 36.4 \mu \mathrm{g} / \mathrm{l})$. In these two groups of patients the serum corticotropin concentrations were not elevated. However, the corticotropin values were increased in the sera of 2 patients with manifested Cushing's disease (one male and one female, 31 and 66 years old respectively).

All the patients underwent pituitary operation, and subsequent morphological evaluation of the tumours revealed 10 null-cell adenomas, 8 sparsely granulated "prolactin cell" adenomas, two corticotropin cell adenomas, one oncocytoma and one mixed densely granulated somatotropin- and sparsely granulated prolactin-cell adenoma. Samples of the tumours were cultured in vitro, and later analysis showed that 8 of them contained pituitary gland tissue, while the remaining 14 adenomas showed no indication of the presence of pituitary gland.

\section{Hormone assay}

Corticotropin was determined in sera and culture media by IRMA, using the kit of CIS bio international (France). Coefficients of variation were below $10 \%$ and the detection limit for corticotropin was $2 \mathrm{ng} / \mathrm{l}$ (reference plasma values were $10-75 \mathrm{ng} / \mathrm{l}$ ). Background values of corticotropin determined for the plain culture media used as a control were $<2 \mathrm{ng} / \mathrm{l}$.

1) $\mathrm{TBP}=$ Tumour Basic Protein

\section{Morphological studies}

A portion of surgically removed pituitary adenoma was fixed in 40 $\mathrm{g} / \mathrm{l}$ buffered paraformaldehyde, dehydrated in graded ethanol, and embedded in paraffin. An identical fixation procedure was applied to the adenoma explants obtained after surgical removal of the tumour, which were also used for the in vitro studies. Paraffin sections of 4 to $6 \mu \mathrm{m}$ thickness were stained with hematoxylineosin, Mallory 3-chrome and the periodic acid-Schiff technique. For the immunohistochemical detection of the pituitary hormones, the immunoperoxidase technique was used. Antisera for the following hormones were used: thyrotropin (diluted 1:500), prolactin (1:300), corticotropin $(1: 400)$, somatotropin (1:500), follitropin $(1: 150)$ and lutropin (1:700) (all by DAKO (Danmark)). Normal pituitary tissue obtained at the autopsy served as positive control. The specificity of each primary antiserum was previously verified by adsorption with its respective primary antigen. For the electron microscopic study, the portion of the adenoma tissue was fixed in buffered $40 \mathrm{~g} / 1$ paraformaldehyde, processed in buffered $20 \mathrm{~g} / \mathrm{l}$ osmium tetroxide, then embedded in Epon 812 . Semithin sections, stained with toluidine blue, were examined to select the areas appropriate for the ultrastructural study. The ultrathin sections of 15 $\mathrm{nm}$ stained with uranyl-acetate and lead-citrate, were studied in an Opton-Zeiss electron microscope EM 9S-2.

\section{Preparation of the bioactive fraction of the human plasma ultrafiltrate}

For the preparation of the bioactive fraction of the human plasma ultrafiltrate (tentatively termed as $\mathrm{TBP}^{1}$ ) ) the pooled EDTAplasma of 49 healthy, male (20-35 years old) blood donors (hepatitis and HIV negative) was used. A sample of 11 was repeatedly filtered on an Amicon membrane ultrafiltration system using a $30000 M_{\mathrm{r}}$ cut-off membrane (Amicon, Ireland) under nitrogen pressure, in a stirred ultrafiltration cell. The eluant was further repeatedly applied to the same ultrafiltration system using a $3000 M_{\mathrm{r}}$ cut-off membrane. The final retentate of $50 \mathrm{ml}$ volume was lyophilised and $5 \mathrm{mg}$ of the lyophilisate was used for further purification by anion exchange fast protein liquid chromatography (FPLC). Anion-exchange chromatography was performed on FPLC, Mod. LCC 500 (Pharmacia, Sweden) using a $1 \mathrm{ml} \mathrm{Re-}$ source-Q-column (Pharmacia, Sweden) equilibrated with 10 $\mathrm{mmol} / \mathrm{l}$ Tris-buffer ( $\mathrm{pH} \mathrm{8.0)}$.

Lyophilised 3000-30000 $\mathrm{M}_{\mathrm{r}}$ plasma ultrafiltrate was dissolved in water $\left(5 \mathrm{mg}\right.$ powder per $0.5 \mathrm{ml}$ Tris $\mathrm{H}_{2} \mathrm{O}$ ) and applied to the column. Column elution was started with $5 \mathrm{ml}$ of Tris-buffer, followed by a salt gradient of $0.5 \mathrm{ml} \mathrm{NaCl}$ in the same buffer within $30 \mathrm{~min}$, increasing finally to $1 \mathrm{~mol} / 1 \mathrm{NaCl}$ in $5 \mathrm{~min}$ (chromatogram in figure 1). Two ml of fractions were collected and biological activity of all the fractions was tested in vitro. According to its "immunomodulating" activity for cultured human lymphocytes (12), a particular fraction (No. 9-TBP; eluted after $12 \mathrm{ml}$ ) was chosen for further analysis. This was lyophilised and kept at $+4^{\circ} \mathrm{C}$. Further analyses of TBP composition (fig. 2) using SMART Mini-Q anion-exchanger sepharose (Pharmacia, Sweden) revealed that TBP behaves as a "double-peak" compound with a dominating sharp peak eluting at approximately $35 \%$ of solvent $\mathrm{B}(10 \mathrm{mmol} / 1 \mathrm{Tris} / \mathrm{HCl}+250$ $\mathrm{mmol} / \mathrm{l} \mathrm{NaCl}$ ). Due to lack of material, further purification and analysis of TBP have not yet been possible.

For experimental purposes the sample of TBP was dissolved in saline, filtered through a $500 M_{\mathrm{r}}$ cut-off membrane using saline as elution liquid. The retentate was passed through a $0.22 \mu \mathrm{m}$ filter (Millipore, USA) and aliquots were kept at $-20^{\circ} \mathrm{C}$, until used in vitro at a concentration of $100 \mathrm{~g} / \mathrm{l}$ plasma equivalent concentration (approximately $5 \mu \mathrm{g} / \mathrm{l}$ ).

\section{Adenoma tissue explant cultures}

Pituitary adenoma tissue was collected in iced saline with penicillin and streptomycin at the time of operation and washed twice with the same solution. Afterwards, the weight of the wet tissue was measured under sterile conditions, and the specimen was dissected into equal pieces of approximately $4-6 \mathrm{~mm}^{3}$ size. The weight of the tissue particles was measured again and the samples were 
Tab. 1 Characteristics of patients and pituitary adenoma tissue explants used for in vitro analysis.

\begin{tabular}{|c|c|c|c|c|}
\hline $\begin{array}{l}\text { Patient - } \\
\text { sex/age }\end{array}$ & $\begin{array}{l}\text { Clinical findings } \\
\text { of adenoma } \\
\text { secretory activity }\end{array}$ & $\begin{array}{l}\text { Pathological diagnosis of the } \\
\text { operated tumour specimen }\end{array}$ & $\begin{array}{l}\text { Serum } \\
\text { corticotropin } \\
(\mathrm{ng} / \mathrm{l})\end{array}$ & $\begin{array}{l}\text { Morphology } \\
\text { of tissue explant cultures* }\end{array}$ \\
\hline 1. $\$ / 65$ & non-functioning & null-cell adenoma & 12.2 & chromophobic adenoma \\
\hline 2. $\delta / 65$ & non-functioning & null-cell adenoma & 8.5 & chromophobic adenoma \\
\hline 3. $9 / 65$ & prolactinoma & sparsely granulated prolactinoma & 12.3 & chromophobic adenoma \\
\hline 4. $\$ / 28$ & prolactinoma & sparsely granulated prolactinoma & 22.5 & chromophobic adenoma \\
\hline 5. $\delta / 28$ & prolactinoma & sparsely granulated prolactinoma & 19.9 & chromophobic adenoma \\
\hline 6. $9 / 38$ & non-functioning & null-cell adenoma & 9.9 & chromophobic adenoma \\
\hline 7. $\$ / 28$ & prolactinoma & sparsely granulated prolactinoma & 12.9 & chromophobic adenoma \\
\hline 8. $\$ / 70$ & non-functioning & null-cell adenoma & 16.3 & chromophobic adenoma \\
\hline 9. $9 / 37$ & acromegaly & $\begin{array}{l}\text { mixed densely granulated somatotropin } \\
\text { cell adenoma and sparsely granulated. } \\
\text { prolactinoma }\end{array}$ & 1.5 & chromophobic adenoma \\
\hline 10. $\$ / 25$ & non-functioning & null-cell adenoma & 16.5 & chromophobic adenoma \\
\hline 11. $\delta / 33$ & non-functioning & null-cell adenoma & 24.8 & chromophobic adenoma \\
\hline 12. $\$ / 70$ & non-functioning & null-cell adenoma & 28.1 & chromophobic adenoma \\
\hline 13. $\delta / 76$ & non-functioning & oncocytoma & 1.5 & oncocytoma \\
\hline 14. 위/51 & non-functioning & null-cell adenoma & 0.6 & chromophobic adenoma \\
\hline 15. 일1 & Cushing's disease & $\begin{array}{l}\text { corticotropin-cell adenoma associated } \\
\text { with Cushing's disease }\end{array}$ & 228.6 & $\begin{array}{l}\text { chromophobic adenoma } \\
\text { mixed with pituitary gland }\end{array}$ \\
\hline 16. $\delta / 57$ & prolactinoma & sparsely granulated prolactinoma & 27.6 & $\begin{array}{l}\text { chromophobic adenoma } \\
\text { mixed with pituitary gland }\end{array}$ \\
\hline 17. $\delta / 41$ & prolactinoma & sparsely granulated prolactinoma & 7.0 & $\begin{array}{l}\text { chromophobic adenoma } \\
\text { mixed with pituitary gland }\end{array}$ \\
\hline 18. $\delta / 37$ & non-functioning & null-cell adenoma & 11.3 & $\begin{array}{l}\text { chromophobic adenoma } \\
\text { mixed with pituitary gland }\end{array}$ \\
\hline 19. $\delta / 41$ & non-functioning & null-cell adenoma & 22.1 & $\begin{array}{l}\text { chromophobic adenoma mixed } \\
\text { with pituitary gland }\end{array}$ \\
\hline 20. $\delta / 66$ & Cushing's disease & $\begin{array}{l}\text { corticotropin cell adenoma associated } \\
\text { with Cushing's disease }\end{array}$ & 221.0 & $\begin{array}{l}\text { chromophobic adenoma mixed } \\
\text { with pituitary gland }\end{array}$ \\
\hline 21. $\$ / 40$ & prolactinoma & sparsely granulated prolactinoma & 17.4 & $\begin{array}{l}\text { chromophobic adenoma mixed } \\
\text { with pituitary gland }\end{array}$ \\
\hline 22. 아/28 & prolactinoma & sparsely granulated prolactinoma & 31.7 & $\begin{array}{l}\text { chromophobic adenoma mixed } \\
\text { with pituitary gland }\end{array}$ \\
\hline
\end{tabular}

* - there were no major differences of the tissue morphology observed between the experimental and the respective control adenoma tissue explant cultures

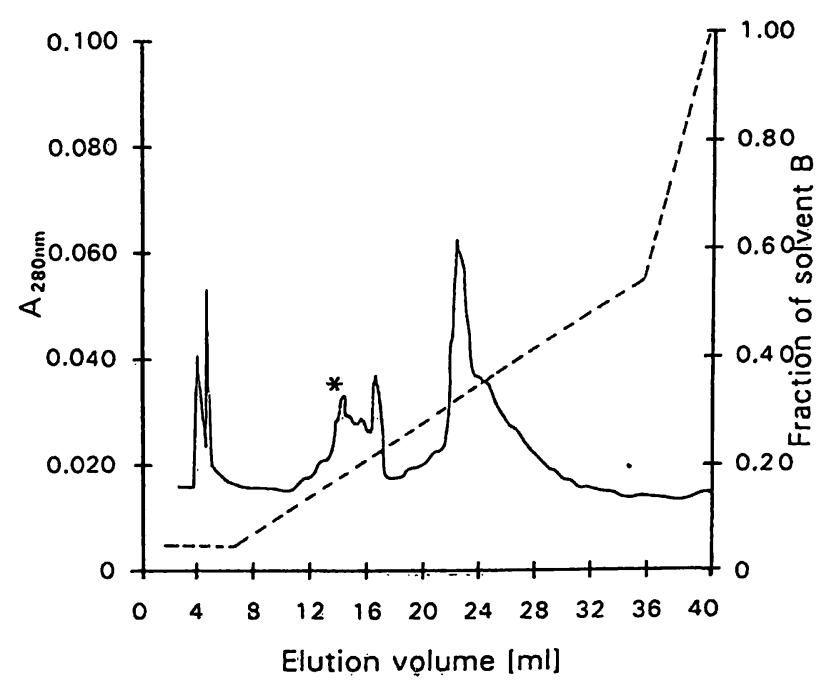

Fig. 1 Preparative anion-exchange liquid chromatography of the human plasma $3000-30000 M_{\mathrm{r}}$ membrane ultrafiltrate. Lyophili-

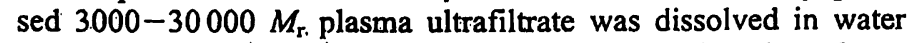
( $5 \mathrm{mg}$ powder $/ 0.5 \mathrm{ml}$ Tris $\mathrm{H}_{2} \mathrm{O}$-solvent $\mathrm{A}$ ), applied to the column and eluted with $5 \mathrm{ml}$ of Tris-buffer followed by a salt gradient of $0.5 \mathrm{ml} \mathrm{NaCl}$ in the same buffer (solvent $\mathrm{B}=$ solvent $\mathrm{A}+1 \mathrm{~mol} / \mathrm{l}$ $\mathrm{NaCl}$ ) within $30 \mathrm{~min}$, finally increasing to $1 \mathrm{~mol} / \mathrm{l} \mathrm{NaCl}$ in $5 \mathrm{~min}$. * - Bioactive fraction (No. 9) used for the in vitro experiments; tentatively termed as TBP. placed in plastic Petri dishes (Greiner, Germany) containing Dulbecco's Modified Eagle's Medium Ham's F-12 supplemented with fetal calf serum (volume fraction 0.1 ) and $1 \mathrm{mU} / \mathrm{l}$ penicillin and $1 \mathrm{mg} / \mathrm{l}$ streptomycin. The culture medium of the tissue explant cultures treated with TBP contained the sample of bioactive plasma ultrafiltrate fraction at $100 \mathrm{~g} / \mathrm{l}$ plasma equivalent. The volume of the medium used for tissue explant cultures depended on the weight of adenoma tissue, thus the ratio was $2 \mathrm{ml}$ medium per $10 \mathrm{mg}$ tissue. Tissue explants were first incubated at $37^{\circ} \mathrm{C}$ in humidified air containing $5 \% \mathrm{CO}_{2}$ for 1 hour without any treatment (for the comparison of the basic hormone secreting activity which appeared to be equal for equivalent samples of the same tumour) and then for 24 hours in the plain medium or in the medium containing TBP.

Afterwards, the medium was removed and stored at $-20^{\circ} \mathrm{C}$ until radioimmunoassay, while the tissue was fixed for morphological analysis as described. Simultaneously, the same amount of medium was incubated in the same way without any pituitary tissue, for determination of the corticotropin background.

\section{Statistics}

Differences between the absolute values of corticotropin determined in the culture media of the control and TBP incubated adenoma tissue explants were evaluated by the Mann-II'hitney$U$ test. Modulation by TBP of the corticotropin secretory activity of the pituitary adenomas in relation to their basic hormone secretory activity was evaluated using the Spearman rank correlation. 


\section{Results}

The values of corticotropin found in the culture media of adenomas that were surgically removed without pituitary gland tissue (as revealed by histology, tab. 1) then incubated in the plain medium or in the medium containing TBP are presented in figure 3 and in table 2 . If the hormone values determined for the control media were relatively high $(>200 \mathrm{ng} / \mathrm{l})$, addition of TBP to the culture medium resulted in a strong decrease of cor-

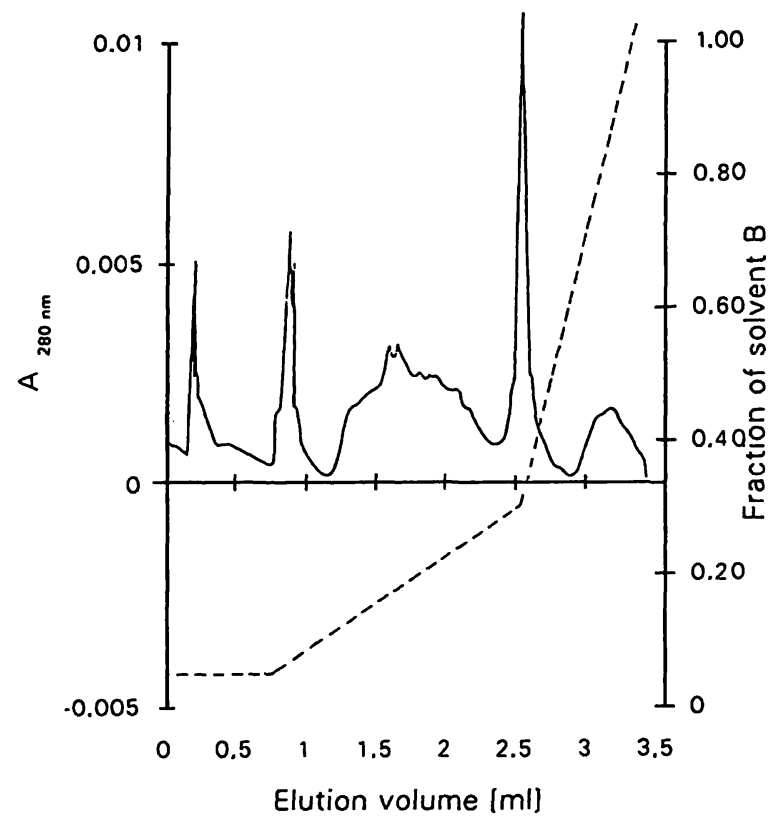

Fig. 2 Analytical anion-exchange liquid chromatography of the bioactive fraction of human plasma $3000-30000 M_{\mathrm{r}}$ membrane ultrafiltrate.

Lyophilised TBP (amount corresponding to approximately $50 \mathrm{ml}$ of plasma) was dissolved in $25 \mu \mathrm{l}$ of $10 \mathrm{mmol} / 1 \mathrm{Tris} / \mathrm{HCl}$ buffer (pH 8) - solvent $\mathrm{A}$, diluted $1: 10$ by $\mathrm{H}_{2} \mathrm{O}$ and applied to SMART Mini- $Q$ anion-exchanger Sepharose using a linear $250 \mathrm{mmol} / \mathrm{I} \mathrm{NaCl}$ gradient in the same buffer (solvent $\mathrm{B}=$ solvent $\mathrm{A}+250$ $\mathrm{mmol} / \mathrm{l} \mathrm{NaCl}$ ).

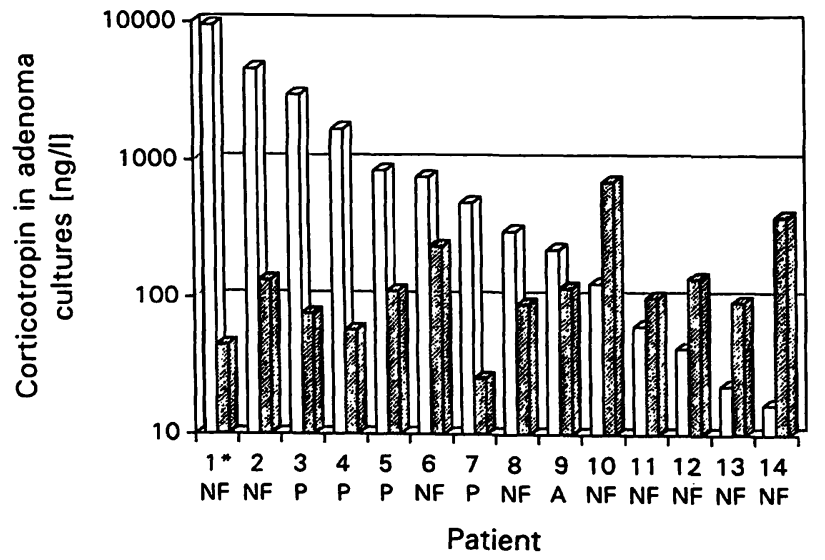

Fig. 3 The effects of TBP on corticotropin release in vitro from the pituitary adenomas incubated as tissue explants without pituitary gland tissue.

Effects of TBP (shaded bars) on corticotropin release in the culture medium (ng/l - d) are presented in comparison with the respective adenoma incubated in the plain medium only (opened bars).

* - patient number (according to the tab. 1) and clinical diagnosis of the respective adenoma secretory activity; NF - non-functioning, $\mathrm{P}$ - prolactinoma, $\mathrm{A}$ - acromegaly. ticotropin concentration $(P=0.0008)$. In contrast, if the tumours showed a lower capacity for corticotropin secretion in vitro $(<200 \mathrm{ng} / \mathrm{l})$, addition of TBP increased their corticotropin secreting activity $(P=0.0283)$. Thus, for the in vitro high corticotropin secreting adenomas the inhibition' 'of the hormone release ranged from $47-99 \%$, while the stimulated hormone release observed for the low corticotropin secreting tumours was $162-2370 \%$ of the respective basic control hormone secreting activity. Furthermore, while immunohistochemistry of the control "high corticotropin secreting" tumours revealed weak corticotropin positivity in only one adenoma tissue explant culture, corticotropin positivity was observed for almost all those adenoma explants incubated with TBP, for which inhibition of the corticotropin in the culture medium was noticed.

Such effects of TBP on the corticotropin secreting activity of the pituitary tumours in vitro were observed only for those tumours removed by surgery without pituitary gland tissue. If the samples of tissue explant cultures contained pituitary gland tissue in addition to adenomatous tissue (as revealed by histology, tab. 1) (fig. 4 and tab. 3), addition of $\mathrm{TBP}^{1}$ ) did not produce any regular and significant effect $P>0.1$ ). Although high corticotropin concentrations $(>200 \mathrm{ng} / \mathrm{l}$ ) were measured in the medium of all these cultures, a moderate decrease (approximately $50 \%$ or less) of the corticotropin concentration in the culture medium was noticed for three tissue explant cultures only. Moreover, for two other samples of this group TBP was even stimulatory (above $250 \%$ of the respective control value), in spite of the high corticotropin concentrations in the control culture medium. Immunohistochemistry of the control tissue explant cultures showed moderate to strong corticotropin positivity in four tumours. For all of these, addition of TBP to the culture medium decreased corticotropin positivity in the tumour cells, although there was no obvious change of the hormone concentration in the culture medium. Widespread corticotropin staining of the normal pituitary tissue was noticed in all the tissue explants, in the control samples, and in the TBP treated tissue explants.

Furthermore, there was a strong negative correlation $(r=-0.92, P<0.01)$ between the dependence of the biomodulating effects of TBP on the corticotropin secretory activity of the pituitary adenomas and their basic hormone secretory activity (fig. 5); such a correlation was not observed for the samples of pituitary adenomas incubated with the pituitary gland tissue $(r=-0.14$, $P>0.1$ ). Thus, while TBP did not influence corticotropin release from the tissue explant cultures of the tumours mixed with the pituitary gland tissue, the dual effect of TBP on corticotropin secretion in vitro, i. e. inhibition of the secreting activity of "high corticotropin secreting" tumours and stimulation of corticotropin secretion of "low corticotropin secreting" tumours was 
Tab. 2 Comparison of the corticotropin secretory activity and immunohistochemistry (corticotropin positivity) of the pituitary adenoma explants without normal pituitary gland tissue.

\begin{tabular}{|c|c|c|c|c|c|}
\hline $\begin{array}{l}\text { Patient - } \\
\text { sex/age }\end{array}$ & $\begin{array}{l}\text { Clinical findings } \\
\text { of adenoma } \\
\text { secretory activity }\end{array}$ & $\begin{array}{l}\text { Control } \\
\text { adenoma } \\
\text { tissue explant } \\
\text { culture cortico- } \\
\text { tropin secretory } \\
\text { activity (ng/l) }\end{array}$ & $\begin{array}{l}\text { Relative values of } \\
\text { adenoma tissue } \\
\text { explant culture } \\
\text { corticotropin } \\
\text { secretory activity } \\
\text { in presence of TBP } \\
\text { (\% of the respective } \\
\text { control value) }\end{array}$ & $\begin{array}{l}\text { Immuno- } \\
\text { histochemistry } \\
\text { (corticotropin } \\
\text { positivity) of the } \\
\text { adenoma cells in the } \\
\text { control adenoma } \\
\text { tissue explant } \\
\text { cultures }\end{array}$ & $\begin{array}{l}\text { Immuno- } \\
\text { histochemistry } \\
\text { (corticotropin } \\
\text { positivity) of the } \\
\text { adenoma cells in the } \\
\text { tissue explants } \\
\text { cultured in presence } \\
\text { of TBP }\end{array}$ \\
\hline 1. $8 / 65$ & non-functioning & 9500.0 & 0.5 & negative* & + \\
\hline 2. $\delta / 65$ & non-functioning & 4619.0 & 2.9 & negative & +++ \\
\hline 3. $9 / 27$ & prolactinoma & 3000.0 & 2.6 & + & ++ \\
\hline 4. $\$ / 28$ & prolactinoma & 1698.0 & 3.4 & negative & + \\
\hline 5. $\delta / 28$ & prolactinoma & 857.0 & 13.2 & negative & $+t$ \\
\hline 6. $9 / 38$ & non-functioning & 761.0 & 31.3 & negative & ++ \\
\hline 7. $9 / 28$ & prolactinoma & 498.3 & 5.9 & negative & negative \\
\hline 8. $\$ / 70$ & non-functioning & 308.0 & 29.2 & negative & negative \\
\hline 9. $9 / 37$ & acromegaly & 226.6 & 52.3 & negative & not done \\
\hline 10. \%/25 & non-functioning & 127.7 & 548.1 & negative & negative \\
\hline 11. $\delta / 33$ & non-functioning & 62.1 & 162.2 & negative & negative \\
\hline 12. $\$ / 70$ & non-functioning & 42.8 & 324.8 & negative & negative \\
\hline 13. $\delta / 76$ & non-functioning & 22.8 & 409.7 & negative & netative \\
\hline 14. $\$ / 51$ & non-functioning & 16.5 & 2369.7 & negative & not done \\
\hline
\end{tabular}

$\begin{array}{ll}*-\text { negative } & \begin{array}{l}\text { no positive cells } \\ \text { weak positivity }(<5 \% \text { of the cells) } \\ \text { moderate staining (approximately } 25 \% \text { of the } \\ ++\end{array} \\ \begin{array}{l}\text { cells) } \\ \text { strong staining }(50-75 \% \text { of the cells) }\end{array}\end{array}$

strong and regular, provided the adenoma tissue was removed without traces of the surrounding pituitary gland.

\section{Discussion}

The results obtained show that the human plasma ultrafiltrate bioactive fraction (TBP) contains potent factor(s) which regulate(s) secretion of corticotropin from the human pituitary adenoma tissue explants in vitro. The na-

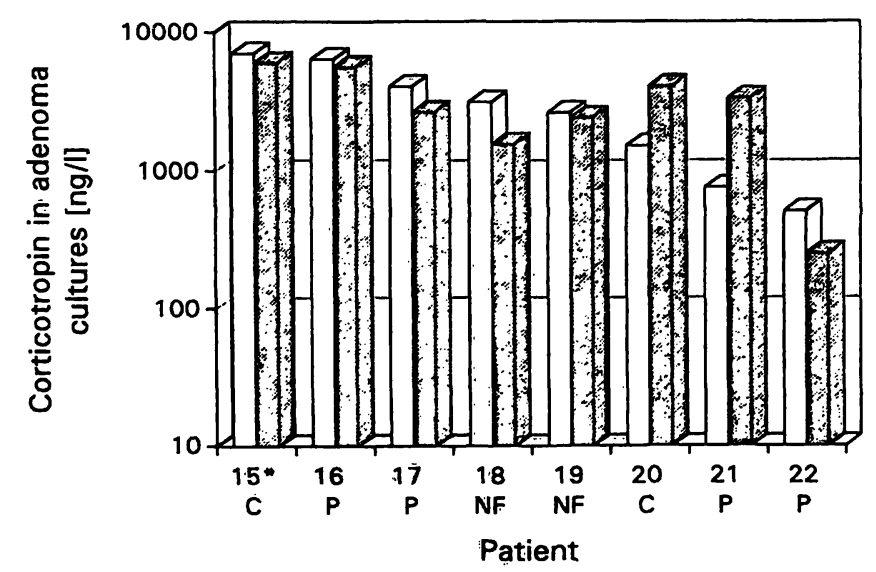

Fig. 4 The effects of TBP on corticotropin release in vitro from the pituitary adenomas incubated as tissue explants in the presence of pituitary gland tissue.

Effects of TBP (shaded bars) on corticotropin release in the culture medium (ng/l-d) are presented in comparison with the respective adenoma incubated in the plain medium only (opened bars).

* - patient number (according to the tab. 1) and clinical diagnosis of the respective adnoma secretory activity; NF - non-functioning, $\mathrm{P}$ - prolactinoma; C - Cushing's disease.
According to Katznelson et al. (13) tissue explants were cultured for 24 hours in the plain medium (control) or in the medium containing bioactive fraction ( $100 \mathrm{~g} / \mathrm{l}$ plasma equivalent concentration) of the human plasma ultrafiltrate (TBP).

ture of the active component of TBP is not yet defined. However, it might be similar to the growth modifying factor found as a heat and acid resistant component in different tissues and culture media $(12,14,15)$. Similar factors modifying tumour cell behaviour have been described under various names (depending on the source of preparation, method of purification and the bioassay used for determination of the activity) (16-21). The basic principle of the biological activity of TBP is still uncertain, but it appears to be a ubiquitous factor that modifies cellular activity. Due to its ability to pass through a $M_{\mathrm{r}} 30000$ cut-off membrane and inability to pass through a $M_{\mathrm{r}} 3000$ cut-off membrane, the $M_{\mathrm{r}}$ of TBP should be within the range of numerous bioactive peptides and low $M_{\mathrm{r}}$ proteins $(20,22)$. TBP cannot be a non-specific very low $M_{\mathrm{r}}$ component (like hydrocortisone, cAMP, etc.) since the $M_{\mathrm{r}}$ of such factors is below 3000. Thus it is not yet known, whether TBP is a new bioactive plasma (and/or tissue) factor. Preliminary data indicate that TBP could also influence the reactivity of the human peripheral blood mononuclear cells to phytohaemagglutinin, stimulating the reactivity of poorly reactive cells and inhibiting the reactivity of highly reactive cells (12).

Similarly, the results show that the effects of TBP on corticotropin release from the cultured pituitary adenomas depended on the basal corticotropin secreting activity of the adenomas. Thus, TBP inhibited (on average more than $90 \%$ ) corticotropin release from the adenomas that exerted relatively high basic hormone release 


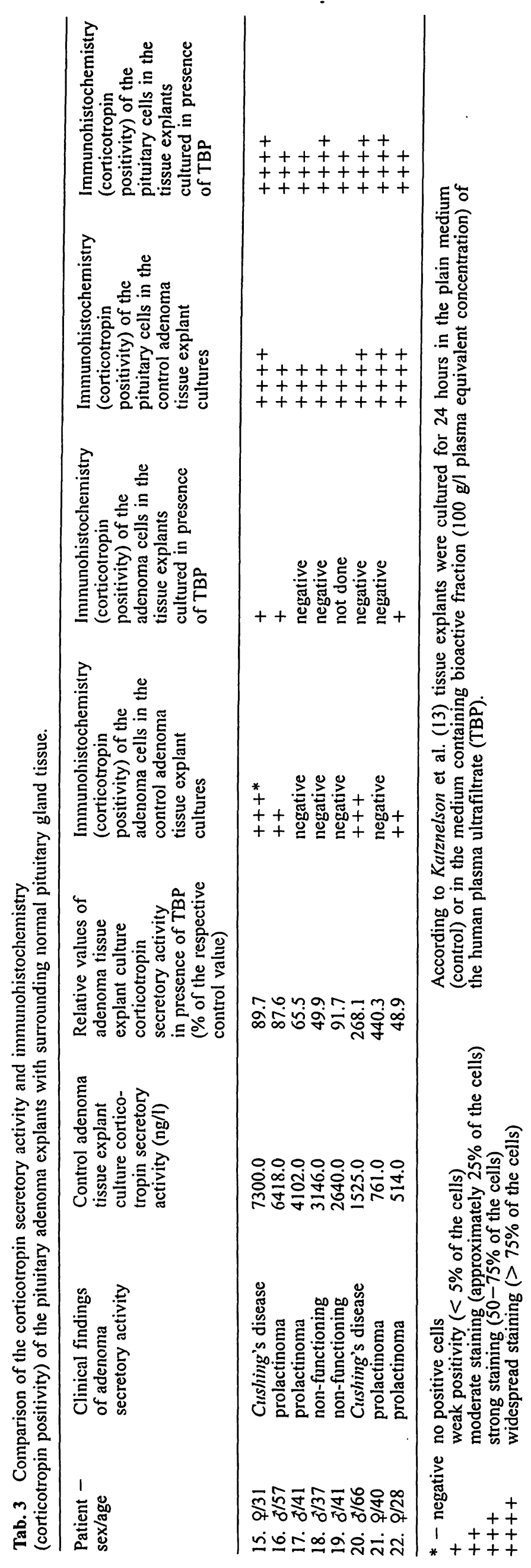

( $200 \mathrm{ng} / \mathrm{l}$ in 24 hours appeared to be the minimal released control corticotropin value which was inhibited). In contrast, TBP stimulated corticotropin release (on average up to four-fold) by the adenomas that exerted relatively low ( $<200 \mathrm{ng} / \mathrm{l}$ in 24 hours) basic hormone release. Furthermore, almost opposite results were obtained for corticotropin immunohistochemistry and corticotropin concentration in the medium of the control and TBP treated "high corticotropin secreting" adenomas, indicating that TBP inhibition was actually prevented of the release of the hormone into the culture medium.

In tissue explant cultures of the "low corticotropin secreting" tumours, increase of corticotropin concentration in the culture medium was not associated with any obvious change of the cellular corticotropin immunoreactivity. Hence, either the TBP activity mechanism was different for the high and for the low corticotropin secreting (or releasing) adenomas, or immunohistochemistry could not reveal corticotropin in the "low corticotropin secreting" tumours.
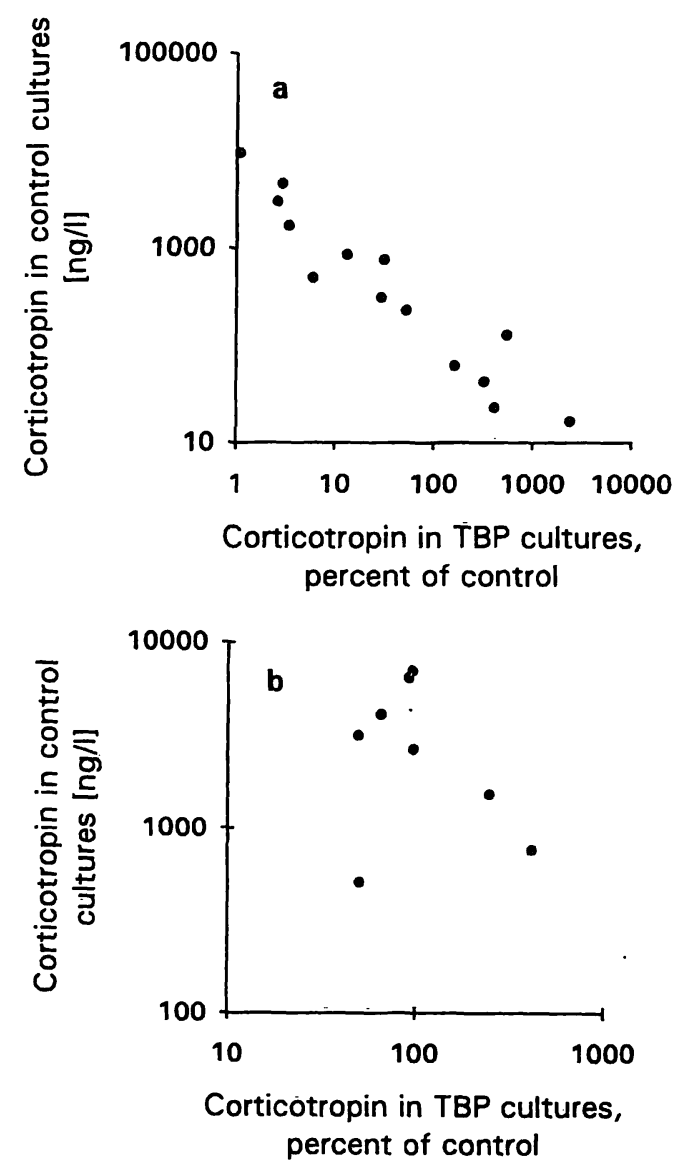

Fig. 5 Dependence of the effects of TBP on the corticotropin secretory activity of the cultured pituitary adenomas in relation to their basic corticotropin secretion in vitro.

A - samples of the pituitary adenomas cultured without pituitary gland; B - samples of the pituitary adenomas cultured with surrounding pituitary gland tissue.

The relative effects of TBP (expressed as percentage of the hormonal activity measured for the same tumours incubated in the plain culture medium) were compared by using the Spearman rank correlation. 
Such effects of TBP were not observed if the adenoma samples contained pituitary gland tissue. That was a surprising finding, since most of these samples showed a very high basic corticotropin secretion, so that a relatively strong inhibition by TBP could be expected. There are at least two possible explanations for this ineffectiveness of TBP. Thus, either TBP could not suppress corticotropin release from the pituitary gland in these tissue explant cultures, or it could not suppress corticotropin release from the adenoma tissue, due to interference by the tumour and pituitary gland corticotropin secretion.

In favour of the first possibility is the presence of high corticotropin in the culture media of the normal pituitary gland (23) and widespread immunohistochemical positivity to corticotropin in the normal pituitary surrounding adenoma tissue, which was not influenced by TBP treatment. The finding of decreased immunohistochemical positivity of the tumour cells after treatment with TBP, with no effect on corticotropin concentration in the culture medium of the adenomas incubated with the surrounding pituitary gland, could indicate that TBP has a different effect on normal pituitary and adenoma cells, i. e. stimulating the release of corticotropin from the tumour cells, but not affecting corticotropin metabolism in the normal cells. However, this possibility should be verified by further experimental studies.

The second possibility cannot be excluded, since it was not possible to distinguish release of corticotropin from the adenoma and corticotropin release from the surrounding pituitary gland tissue. Moreover, cell to cell communication is of high importance in the regulation of corticotropin secretion (24), and the integrity of the tumourous and surrounding pituitary tissue was preserved during incubation of these tissue explants.

On the other hand, it is possible that TBP influenced the hormonal activity of "multipotential pituitary cells"

\section{References}

1. Costello RT. Subclinical adenoma of the pituitary gland. Am J Pathol 1936; 12:205-8.

2. Molitch ME. Pathogenesis of pituitary tumors. In: Kovacs $\mathrm{K}$, editor. Pituitary adenomas: diagnosis and management. Philadelphia: Saunders, 1987:503-27.

3. Reichlin S. Pathogenesis of pituitary tumors. In: Faglia G, editor. Pituitary adenomas. Amsterdam: Excerpta Medica, 1991:113-21.

4. Kohler PO, Bridson WE, Rayford PL, Kholer SE. Hormone production by human pituitary adenomas in culture. Metabolism 1969; 18:782-6.

5. Mashiter K, Adams E, Van Noorden S. Secretion of LH, TSH, and PRL shown by cell culture and immunohistochemistry of human functionless pituitary adenoma. Clin Endocrinol 1981; 15:103-9.

6. Asa SL. In vitro studies of human pituitary adenomas. Pathol Res Pract 1988; 183:561-4.

7. Yamada S, Asa SL, Kovacs K, Muller P, Smith H. Analysis of hormone secretion by clinically nonfunctioning human pitu- which mainly contain corticotropin and play an important role in the regulation of hormone secretion by the other pituitary cells (25).

Furthermore, post-surgical stress (removal of the pituitary tumour) as well as growth factor synthesis by the tumourous tissue in vitro modulate hormone secretion $(26-28)$. It is possible that TBP (bioactive fraction of the human plasma ultrafiltrate) contains factor(s) involved in the stress reaction or paracrine regulation of the growth factor synthesis, thus indirectly affecting the hormone release, but these possibilities have to be further evaluated. Finally, it is not impossible that TBP, like some other bioactive peptides $(29-35)$, is involved in regulation of adenylate cyclase activity and/or calcium metabolism, thereby acting as a regulator of the hormonal activity of the normal and tumourous pituitary tissue.

From the present results, however, it seems that TBP could be the humoral factor involved in the regulation corticotropin release from the pituitary adenoma tissue, but not in the regulation of corticotropin release from normal pituitary tissue. To verify this possibility, it will be necessary not only to analyse the nature of this bioactive component of the human plasma ultrafiltrate but also to use the advantages of the tissue explant culture method to evaluate the effects of TBP on the hormone release from the normal pituitary gland, as well as on the growth features of normal and tumour cells.

\section{Acknowledgements}

This study was supported by Croatian Ministry of Science and Technology, Austrian Science Foundation (FWF) and International Association for Cancer Research (AICR). The authors would like to express their sincere gratitude to Biomedica (Austria) and Mr. Herbert Zakarias for collaboration. itary adenomas using reverse haemolytic plaque assay. $\mathrm{J}$ Clin Endocrinol Metab 1989; 68:73-80.

8. Beck-Peccoz P, Persani L, Medri G, Guerrero MI, Spada A, Faglia G. New aspects in "non-functioning" pituitary tumors. In: Casanueva FF, Dieguez C, editors. Recent advances in basic and clinical neuroendocrinology. B. V.: Elsevier Science Publishers, 1989:295-302.

9. Alexander JM; Jameson JL, Bikkal HA, Schwall RH, Klibanski $A$. The effects of activin on follicle-stimulating hormone secretion and biosynthesis in human glycoprotein hormoneproducing pituitary adenomas. J Clin Endocrinol Metab 1991; 72:1261-7.

10. Klibanski A, Alexander JM, Bikkal HA, Hsu DW, Sivearingen B, Zervas N. Somatostatin regulation of glycoprotein hormone and free subunit secretion in clinically nonfunctioning and somatotroph adenomas in vitro. J Clin Endocrinol Metab 1991; 73:1248-55.

11. Koršić M, Žarković N, Žarković K, Plavšić V, Lovrić M, llić $Z$, et al. The relation of pituitary adenoma hormone levels de- 
termined by immunocytochemical detection and in tissue explant culture media to morphological studies and clinical events. Period Biol 1993: 85:429-36.

12. Žarković N, Hayn M, Schaur JR, Schauenstein K, Jürgens $G$, Benko B, et al. Modification of PHA reactivity of human peripheral blood lymphocytes (PBL) by a growth suppressive human plasma factor. Period Biol 1994; 96:284.

13. Katznelson L, Alexander JM, Bikkal HA, Jameson JR, Hsu DW, Klibanski A. Imbalanced follicle-stimulating hormone $\beta$ subunits in human pituitary adenomas. J Clin Endocrinol Metab 1992; 74:1434-51.

14. Žarković N, Čvoriščec D, Vlahović M, Tvredeić A, Zgaga V, Jurin $M$, et al. Modification of murine brain cells growth in vitro with melanoma B16 regulatory growth factors. Cell Differentiation 1989; 27 Suppl:203.

15. Žarković $N$, Osmak $M$, Novak $Đ$, Lerš $N$, Jurin $M$. The influence of mouse sera, regenerating liver extracts and bacterial products on the abilities of different cells in vitro. Int $\mathrm{J} \mathrm{Dev}$ Biol 1991; 35:239-49.

16. Mondola P, Mariarosaria S, Cammarota L, Santangelo F. Role of a calf thymus preparation in the degradation of a native and reductively methylated low density lipoprotein. Int J Biochem 1991; 23:819-21.

17. Pierce GB, Speers WC. Tumors as caricatures of the process of tissue renewal: prospects for therapy by directing differentiation. Cancer Res 1988; 48:1996-2004.

18. Wells RS, Miotto KA. Widespread inhibition of neuroblastoma cells in the 13- to 17-day-old mouse embryo. Cancer Res 1986; 42:1659-62.

19. Kromer G, Schauenstein K, Dietrich H, Fassler R, Wick G. Mechanisms of $T$ cell hyperreactivity in obese strain (OS) chickens with spontaneous autoimmune thyroiditis: lack in non-specific suppression is due to a primary adherent cell defect. J Immunol 1987; 138:2104-9.

20. Lotem J, Takeda K. Regulatory growth and differentiation factors. Status Differentiation Ther 1991; 2:107-13.

21. Matsumoto K, Tajima H, Hamanoue M, Kohno S, Knoshita T, Nakamura T. Identification and characterisation of "injurin", an inducer of expression of the gene for hepatocyte growth factor. Proc Natl Acad Sci USA 1992; 89:2800-4.

22. Habenicht A, editor. Growth factors, differentiation factors, and cytokines. Berlin: Springer-Verlag, 1990.

23. Asa SL, Gerrie BM, Singer W, Horvath E, Kovacs K, Smith HS. Gonadotropin secretion in vitro by human pituitary null cell adenomas and oncocytomas. J Clin Endocrinol Metab 1986; 62:1011-9.

24. Schwartz J, Canny B, Vale W, Funder J. Intrapituitary cell-cell communication regulates ACTH secretion. Neuroendocrinology $1989 ; 50: 716-22$.
25. Childs G. Multipotential pituitary cells that contain adrenocorticotropin (ACTH) and other pituitary hormones. Trends Endocrinol Metab 1991; 2:112-7.

26. Jessop DS, Chowdrey HS, Larsen PJ, Lightman SL. Substance P. Multifunctional peptide in hypothalamo-pituitary system. J Endocrinol 1992; 132:331-7.

27. Brunetti L, Preziosi, Ragazzoni E, Vacca M. Effects of lipopolysaccharide on hypothalamic-pituitary-adrenal axis in vitro. Life Sci 1994; 54:10-5.

28. Webster J, Ham J, Bevan JS, Ten Horn CD, Scanlon MF. Preliminary characterisation of growth factors secreted by human pituitary tumors. J Clin Endocrinol Metab 1991; 72:687-91.

29. Spada A, Reza-Elahi F, Lania A, Bassetti M, Atti E. Inhibition of basal and corticotropin-releasing hormone-stimulated adenylate cyclase activity and cytosolic $\mathrm{Ca}^{2+}$ levels by somatostatin in human corticotropin-secreting adenomas. J Clin Endocrinol Metab 1990; 70:1262-8.

30. Won GSJ, Orth DN. Roles of intracellular and extracellular calcium in the kinetic profile of adrenocorticotropin secretion by perfused rat anterior pituitary cells. I. corticotropin-releasing factor stimulation. Endocrinology 1990; 126:849-57.

31. Won GSJ, Orth DN. Roles of intracellular and extracellular calcium in the kinetic profile of adrenocorticotropin secretion by perfused rat anterior pituitary cells. II. arginine, vasopressin, oxytocin, and angiotensin-II stimulation. Endocrinology $1990 ; 126: 858-66$.

32. Hart GR, Gowing H, Burrin JM. Effects of a novel hypothalamic peptide, pituitary adenylate cyclase-activating polypeptide, on pituitary hormone release in rats. J Endocrinol 1992; 134:33-41.

33. Dow RC, Bennie J, Fink G. Pituitary adenylate cyclase-activating peptide-38 (PACAP-38) is released into hypophysial portal blood in the normal male and female rat. J Endocrinol 1994; 142:R1-R4.

34. Calogero AE, Raiti F, Nicolosi G, Burrello N, D'Agata R, Mantero F. Effects of endothelin-1 and endothelin-3 on rat hypothalamic corticotropin-releasing hormone and pituitary ACTH release in vitro. J Endocrinol 1994; 140:419-24.

35. Desai BJ, Monson JP, Holdstock JG, Aylwin SJB, Geddes JF, Wood DF, Burrin JM. Effects of pituitary adenylate cyclase activating polypeptide on hormone secretion by human pituitary adenomas in vitro. J Clin Endocrinol Metab 1994; 79:1771-6.

Received January 23/May 29, 1995

Corresponding author: Dr. Neven Žarković, Rudjer Bošković Institute, Bijenička 54, HR-10000 Zagreb, Croatia 